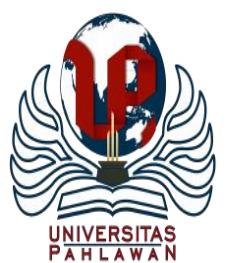

Edukatif : Jurnal Ilmu Pendidikan Volume 3 Nomor 3 Tahun 2021 Halm 698 - 704

EDUKATIF: JURNAL ILMU PENDIDIKAN

Research \& Learning in Education

https://edukatif.org/index.php/edukatif/index

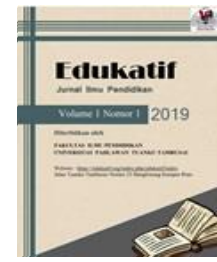

\title{
Peningkatan Hasil Belajar IPA dengan Discovery Learning Berbantuan Media Audio Visual di Sekolah Dasar
}

\author{
Hendika Whesli $^{1 凶}$, Agustina Tyas Asri Hardini \\ Universitas Kristen Satya Wacana, Indonesia ${ }^{1,2}$ \\ E-mail : $\underline{\text { hendikawhes@gmail.com }}{ }^{1},{\underline{\text { agustina.hardini@ } \text { uksw.edu }^{2}}}^{2}$
}

\begin{abstract}
Abstrak
Berdasarkan penelitian pada pendahuluan, diperoleh simpulan bahwa pembelajaran IPA daring belum dilaksanakan secara optimal. Metode yang digunakan bersifat homogen, sumber belajar siswa menggunakan buku tematik, dan rerata hasil belajar IPA kelas V paling rendah dibandingkan mata pelajaran yang lain. Penelitian ini bertujuan untuk mengetahui peningkatan pembelajaran IPA melalui Model Discovery Learning berbantu media audio visual pada siswa kelas V SD Negeri Jogoyitnan dengan jumlah 38 siswa. Jenis penelitian merupakan PTK memakai model Kemmiss dan Mc. Taggart, dengan teknik pengumpulan data yang digunakan adalah teknik tes dan wawancara. Hasil penelitian menunjukkan bahwa: (1) Aktivitas siswa, meliputi: persiapan belajar, aktivitas belajar, motivasi untuk bisa, efektifitas pemanfaatan waktu belajar, dan kemajuan pada siklus I memperoleh skor rerata 14,15 terbilang kategori cukup, mengalami peningkatan pada siklus II menjadi 17,52 dengan kategori baik, (2) Hasil belajar pada siklus I dengan ketuntasan klasikal akhir sebesar 53\% dan mengalami peningkatan pada siklus II menjadi 74\%. dan (3) Siswa lebih menyukai pembelajaran dengan model Discovery Learning karena dalam pembelajaran siswa melakukan percobaan sendiri sehingga pengetahuan didapat lebih utuh dan bermakna. Simpulan dari penelitian ini yaitu melalui model Discovery Learning berbantuan media audio visual bisa menaikan hasil belajar IPA di kelas V SDN Jogoyitnan.
\end{abstract}

Kata Kunci: IPA, Discovery Leaning, Hasil Belajar.

\section{Abstract}

Based on preliminary research, can be concluded that science learning was not optimal. The learning model used was homogeneous, the learning resource for students was using thematic textbooks, and the average of science learning results of fiveth grade students was the lowest compared to other subjects. The purpose of this study was to determine the increase of science learning through the Audio Visual Media-assisted Discovery Learning Model with a total of 38 students. The typeof research is classroom action research with the model of Kemmis and Mc Taggart, data collection techniques used test techniques and interviews. The results showed that: (1) The activities of students in the first cycle obtained an average score of 14.15 with sufficient categories, increased in the second cycle to 17,52 with a good category, (2)Learning outcomes in the realm of the first cycle with final classical completeness of $53 \%$ and increased in the second cycle to $74 \%$, and (3) Students prefer learning with the Discovery Learning model because learning by doing experiments so that the knowledge gained will be more complete and meaningful. The conclusion of this study is Audio Visual Media-assisted Discovery Learning model can increase the outcome science learning in the $V$ class of Jogoyitnan Elementary School.

Keywords: Science Studies, Discovery Learning, Learning Outcome.

Copyright (c) 2021 Hendika Whesli, Agustina Tyas Asri Hardini

$\triangle$ Corresponding author

Email : hendikawhes@gmail.com

DOI : https://doi.org/10.31004/edukatif.v3i3.345

ISSN 2656-8063 (Media Cetak)

ISSN 2656-8071 (Media Online)

Edukatif : Jurnal Ilmu Pendidikan Vol 3 No 3 Tahun 2021 p-ISSN 2656-8063 e-ISSN 2656-8071 


\section{PENDAHULUAN}

Pendidikan merupakan usaha sadar dalam membentuk karakter dan meningkatkan kemampuan serta peradaban bangsa bermartabat untuk mencerdaskan kehidupan bangsa. Tujuan pendidikan senada dengan Pancasila dan UUD 1945. Pendidikan ditujukan guna mengembangkan kemampuan pesdik agar menjadi manusia yang memiliki iman dan taqwa kepada Tuhan Yang Maha Esa, tanggung jawab, beraklak mulia, kreatif, cakap,mandiri, berilmu, sehat, dan demokratis sebagai warga negara(Depdiknas, 2003) .Uraian tersebut berdasarkan peraturan UU No. 20 Tahun 2003 tentang SISDIKNAS untuk memenuhi kebutuhan abad XXI, ruang lingkup materi dan tingkat kompetensi siswa dalam kurikulum 2013 harus dicapai. Ruang lingkup dan kompetensi dirumuskan pada Standar Kompetensi Lulusan yaitu pengetahuan, sikap, dan keterampilan.

Akhir-akhir ini terdapat kendala dalam proses pembelajaran, dikarenakan pandemik Covid-19 yang mengharuskan pendidik dan peserta didik tidak diperbolehkan melakukan pembelajaran secara tatap muka (daring). Berdasarkan realita yang peneliti rasa langsung di kelas V SD Negeri Jogoyitnan pada masa kebiasaan baru pandemi Covid-19, dikarena pandemi Covid-19-yang mewabah dunia terkhusus dunia pendidikan, muncul beberapa permasalahan, diantaranya: (1) Rendahnya hasil belajar siswa, (2) Motivasi belajar siswa rendah dalam ikut pembelajaran, (3) Mudah bosan dikarenakan lama tidak berjumpa dengan guru dan teman-teman. Apabila tidak ditindak lanjuti, maka bisa memunculkan dampak yang kurang baik bagi siswa, guru, serta sekolah. Bagi peserta didik menyebabkan menurunnya prestasi belajar. Bagi guru merasa gagal dalam meningkatkan hasil belajar siswa, sedangkan bagi sekolah akan mengakibatkan redahnya kualitas hasil pembelajaran.

Khususnya dalam muatan pembelajaran IPA KD.3.7 Menganalisis pengaruh kalor terhadap perubahan suhu dan wujud benda dalam kehidupan sehari-hari, berdasarkan perolehan hasil belajar IPA terlihat paling rendah dibandingkan hasil belajar pada muatan pembelajaran lainnya. Diperlukan media bantu pembelajaran yang dapat mengkonkretkan materi pembelajaran sehingga sesuai dengan taraf perkembangan siswa. Proses belajar mengajar konvensional tanpa memperhatikan kerucut pengalaman kurang sesuai untuk taraf perkembangan siswa kelas V SD. Proses belajar mengajar berbantuan komputer dapat meningkatkan kualitas pembelajaran. Komputer sebagai alat bantu yang dipakai guru dalam menyampaikan materi kepada pesdik. Teknologi multimedia dengan komputer mampu menampilkan banyak informasi dengan audio visual yang interaktif (Purwanto \& Riadi, 2013)

Dalam menyingkapi kondisi pandemi covid-19, alternatif model pendidikan yang bisa diterapkan merupakan lewat model pendidikan discovery learning, penulis kolaborasikan dengan media audio visual. Model discovery learning merupakan model yang memusatkan siswa buat menciptakan secara mandiri pemahaman yang wajib dicapai dengan tutorial dan pengawasan guru. Dalam pengaplikasian model Discovery Learning, terdapat prosedur yang wajib dilaksanakan dalam aktivitas belajar mengajar adalah sebagai berikut : (1) Stimulasi/Pemberian Rangsangan, (2) Identifikasi Permasalah, (3) Pengumpulan Informasi, (4) Pengolahan Informasi, (5) Pembuktian, (6) Menarik Kesimpulan (Syah, 2010).Sejalan dengan teori yang disampaikan Plato, anak umur sekolah menengah hendak lebih menguasai pembelajaran yang dilaksanakan bila dilakukan sembari berkreasi (Susmiati, 2020). Melalui model ini siswa diarahkan menggunakan hp untuk membuat video percobaan yang sedang dilakukan. Membuat rekaman video bisa digunakan dalam semua pembelajaran. Namun,penelitian ini memfokuskan di penerapan model pembelajaran IPA pada materi pengaruh kalor terhadap suhu dan wujud benda karena materi tersebut sangat kontekstual pada penerapan di kehidupan seharihari.

Berdasar pada hasil pengambilan data awal pada siswa kelas V muatan IPAKD. 3.7 Menganalisis pengaruh kalor terhadap perubahan suhu dan wujud benda dalam kehidupan sehari-hari bahwa dari 38 siswa terdapat 22 siswa (58\%) belum mecapai KKM yang telah ditentukan yaitu 65.Hanya 16 siswa (42\%) yang 
telah mampu mencapai KKM. Data tersebut menunjukkan bahwa nilai paling tinggi adalah 85 dan nilai paling rendah 25 dengan rata-rata 59,6. Dari informasi tersebut disimpulkan bahwa pelaksanaan pembelajaran IPA belum optimal. Ada pula tujuan riset ini yaitu guna meniingkatkan hasil belajar IPA pada KD. 3.7 menganalisis pengaruh kalor terhadap perubahan suhu dan wujud benda dalam kehidupan sehari-hari dengan model Discovery Learning berbantuan media audio visual pada saat pandemi-covid-19 bagi siswa kelas V SDN Jogoyitnan, Kabupaten Wonosobo.

\section{METODE PENELITIAN}

Penelitian ini dilakukan di SDN Jogoyitnan, Kecamatan Wonosobo, Kabupaten Wonosobo. Subjek penelitian merupakan siswa kelas V SDN Jogoyitnan 38 siswa tterdiri dari 18 siswa laki-laki dan 20 siswa perempuan. Jenis penelitian adalah PTK memakai model Kemmis serta Mc. Taggart (Suharsimi, 2007). Teknik pengumpulan informasi yang dilaksanakan adalah tes, obervasi, dokumentasi dan wawancara. Data kuantitatif adalah hasil belajar siswa. Aspek yang dianalisa pada data ini adalah rerata nilai kelas dan ketuntasan belajar klasikal.

Analisis data tahap pertama untuk menentukan valaditas dan reliabilitas. Uji validitas digunakan guna mngetahui valid tidaknya butir soal,menggunakan rumus korelasi Product Moment di Microsoft Excel. Harga $\mathrm{r}$ yang diperoleh dibandingkan dengan tabel $\mathrm{r}$ product moment taraf signifikan 5\% dengan df (degree of freedom $)=\mathrm{n}$-2. Jika harga $\mathrm{r}_{\text {hitung }}>\mathrm{r}_{\text {tabel }}$, maka butir soal dinyatakan valid (Suharsimi, 2007). Berdasarkan hasil uji coba diperoleh 21 valid dan 9 tidak valid.

Instrumen dinyatakan reliabel apabila dapat membuahkan hasil yang tetap, pada subjek yang sama dilain waktu (Suharsimi, 2007). Alat ukur disebut reliabel jika mempunyai hasil yang konsisten. Penelitian ini memakai rumus K-R 20 (Kuder Richardson) dengan hasil perhitungan $\mathrm{r}_{11}$ dikonsultasikan pada tabel $\mathrm{r}_{\text {product }}$ moment dengan $\mathrm{df}$ (degree of freedom) $=\mathrm{n}-2$, dengan taraf signifikansi $5 \%$.Jika $\mathrm{r}_{11}>\mathrm{r}_{\text {tabel }}$ maka butir soal dibilang reliabel. Diperoleh $r_{\text {hitung }}=0,865$ dan $r_{\text {tabel }}=0,3338$, sehingga butir soal reliabel.

Analisis data tahap kedua dilakukan untuk merefleksi setiap siklus dalam penelitian ini. Hasil refleksi digunakan untuk menentukan perencanaan lanjut dalam siklus selanjutnya. Hasil refleksi ini digunakan untuk memperbaiki rancangan pembelajaran selanjutnya. Kriteria tingkat keberhasilan, meliputi : (1) Tingkat keberhasilan $>80 \%$ berarti sangat tinggi, (2) Tingkat keberhasilan $60-79 \%$ berarti tinggi, (3) Tingkat keberhasilan 40-59\% berarti sedang, (4) Tingkat keberhasilan 20-39\% berarti rendah, dan (5) Tingkat keberhasilan $<20 \%$ berarti sangat rendah (Aqib \& Amrullah, 2018)

Di penelitian ini terdapat data kualitatif berbentuk infromasi hasil observasi aktivitas pesdik dalam pembelajaran IPA KD. 3.7 Menganalisis pengaruh kalor terhadap perubahan suhu dan wujud benda dalam kehidupan sehari-hari. Data kualitatif dipaparkan dalam kalimat yang dipisah menurut kategori untuk memperoleh kesimpulan.Data kualitatif ini didapat dari pengolahan infromasi yang diambil dari aktivitas peserta didik meliputi : persiapan belajar, aktivitas belajar, motivasi untuk bisa, efektifitas pemanfaatan waktu belajar, dan kemajuan (Sugiyono, 2018).

\section{HASIL DAN PEMBAHASAN PENELITIAN}

Perlakuan di penelitian ini dilaksanakan selama dua siklus (tiap siklus dua pertemuan). Tiap siklus terdapat empat tahap yaitu perencanaan, tindakan, observasi, dan refleksi. Dimulai dari perencanaan yaitu : mengidentifikasi KI dan KD kelas V IPA tentang akibat kalor terhadap suhu dan wujud benda; berkonsultasi dengan guru kelas terkait indikator, tujuan, dan materi pembelajaran; Menyusun silabus, RPP, materi pembelajaran, dan scenario pembelajaran melalui model Discovery Learning; menyiapkan media pembelajaran audio visual; menyusun instrumen berupa tertulis pilihan ganda; serta menyiapkan lembar 
observasi aktivitas siswa. Pelaksanaan tindakan yang dilkakukan pada tiap pertemuan sebagai berikut : pra kegiatan,pendahuluan,inti,dan kegiatan penutup. Proses pembelajaran melalui aplikasi Zoom, dengan link yang dibagikan tiap pertemuan di Whatsapp Group.

Setiap siklus, terdapat kegiatan evaluasi untuk mengukur hasil belajar siswa. Penelitian ini dilakukan padaKD. 3.7Menganalisis pengaruh kalor terhadapperubahan suhu dan wujud benda dalam kehidupan seharihari siswa kelas V SDN Jogoyitnan. Pelaksanaan dilaksanakan dalam siklusI dan siklus II.Setelah terlaksana selama dua siklus, setelahnya target penelitian dapat tercapai. Capaian penelitian ini meliputi capaian proses dan hasil. Pemaparan capaian proses adalah aktivitas siswa.

Berikut ini merupakan hasil dari observasi aktivitas siswa pada siklus Idan siklus II :

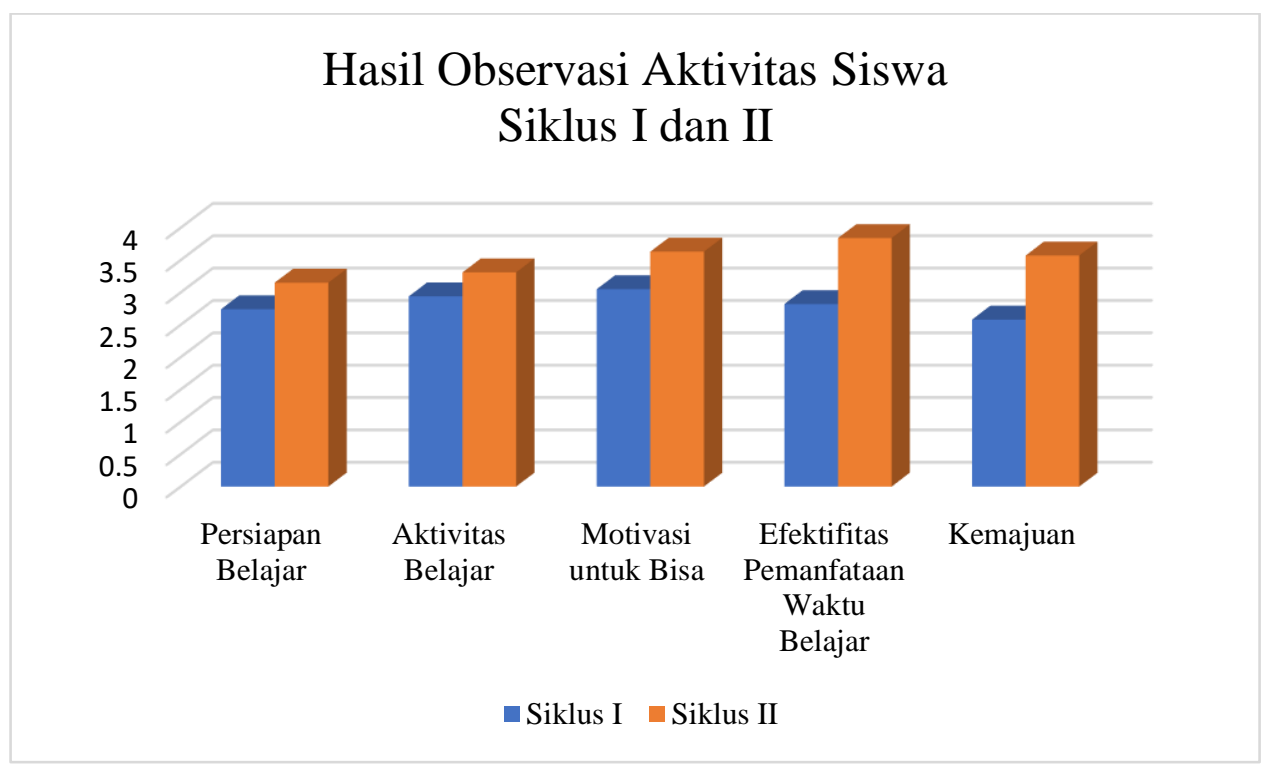

Diagram 1. Hasil Observasi aktivitas siswa siklus I dan II

Menurut diagram diatas dilihat adanya aktivitas peserta didik meningkat. Pada siklus I, skor aktivitas siswa yang didapat adalah 14,15 kriteria cukup.Di siklus II aktivitas siswa meningkat mencapai skor 17,52 dengan kriteria baik. Hasil yang didapat sudah memenuhi indikator keberhasilan yang sudah ditetapkan.

Faktor yang sangat mempengaruhi aktivitas siswa pada penelitian ini adalah pemakaian media pembelajaran. Saat guru tidak memanfaatkan media pembelajaran dengan baik, siswa tidak mendapatkan pengetahuan secara utuh. Dengan penggunaan model belajaran Discovery Learning, guru dapat membimbing siswa lebih kreatif dalam percobaan membuktikan teori tertentu. Guru memakai media audio visual untuk bisameningkatkan motivasi belajar pesdik dan meningkatkan pemahaman siswa. Model pembelajaran Discovery Learning merupakan belajar untuk menemukan, dimana seorang siswa menghadapi masalah dan situasi yang ganjil sehingga siswa bisa menemukan jalan pemecahan ("Pendekatan Realistik Dalam Pembelajaran Matematika,” 2012).

Peningkatan hasil belajar siswa kelasV SDN Jogoyitnan Wonosobo di pembelajaran IPA melalui model Discovery Learning berbantu media audio visual dibagi menjadi tiga ranah hasil belajar yaitu hasil belajar pada ranah pengetahuan, sikap,dan keterampilan. Pada penelitian ini difokuskan pada ranah hasil belajar pengetahuan. Hasil belajar akan dibahas secara detail sebagai berikut : 
Tabel 1. Hasil Belajar

\begin{tabular}{|clccc} 
No & \multicolumn{1}{c}{ Pencapaian } & Prasiklus & Siklus I & Siklus II \\
1 & Rerata & 59,6 & 63,68 & 72,89 \\
2 & Nilai Terendah & 25 & 30 & 50 \\
3 & Nilai Tertinggi & 85 & 85 & 95 \\
4 & KetuntasannKlasikal & $42 \%$ & $53 \%$ & $76 \%$ \\
5 & PeningkatannHasil Belajar & & $11 \%$ & \\
& Prasiklus - Siklus I & & & \\
6 & PeningkatannHasil Belajar & & $23 \%$ & \\
& Siklus I - Siklus II & & &
\end{tabular}

Didasarkan tabel diketahui bahwa, hasil belajar terus alami peningkatan yang cukup baik di tiap siklus, sebab penelitian ini dilaksanakan didasarkan teori perkembangan kognitif yang dikembangkan oleh Jean Piaget bahwa siswa SD di usia 7-11 tahun berada pada tingkatan operasional konkrit. Berarti, pembelajaran pada siswa SD dengan umur tersebut harus bersifat nyata (konkrit). Pelaksanaan pembelajaran dengan model Discovery Learning cukup memuaskan. Ditunjukkan saat mengerjakan LKPD siswa sudah bisa berdiskusi menyelesaikan permasalahan, dalam melakukan berbagai kegiatan dalam pembelajaran seluruh siswa melakukannya dengan tanggung jawab tidak lagi didominasi siswa pintar. Berikut merupakan diagram hasil belajar siswa ranah pengetahuan (kognitif) prasiklus,siklus I,dan siklus II :

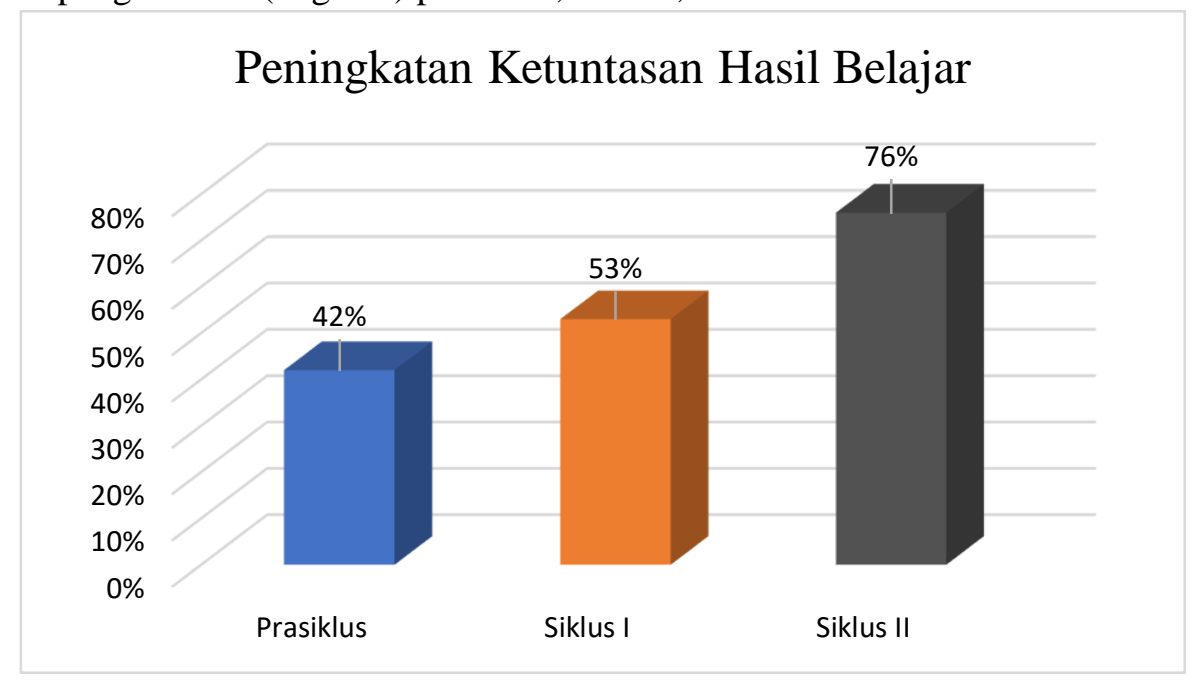

Diagram 2. Peningkatan ketuntasan hasil belajar

Berdasarkan grafik diatas, peningkatan ketuntasan hasil belajar terjadi tiap siklus.Pada siklus II, ketuntasan hasil belajar melampaui target yang ditetapkan yaitu $75 \%$. Selama proses penelitian, ditemukan beberapa temuan diantaranya pada pembelajaran IPA tidak selalu disampaikan dengan ceramah, tetapi butuh metode, pendekatan, strategi bahkan model pembelajaran yang variatif agar siswa bisa lebih aktif dan termotivasi ikut pembelajaran. Sejalan pendapat oleh (Susanto, 2013) bahwa minat berperanan penting dalam menentukan pola, dimensi, dan arah belajar di aktivitas pembelajaran. Peneliti memakai model Discovery Learning, dikarena peserta didik melaksanakan percobaannya sendiri, untuk anak usia SD melakukan percobaan akan lebih menarik, dengan percobaan siswa melaksanakan penemuannya sendiri, bukan hanya teori yang diterima, namun terdapat kesinambungan dan bukti antara fakta dengan terori. Sejalan dengan hasil penelitian oleh (Mahartati, 2017) Discovery Learning merupakan model pembelajaran yang materinya tidak 
disampaikan utuh, sebab model discovery learning mengharap siswa menemukan sendiri konsep pembelajaran dan aktif ikut pembelajaran.

Dari pemaparan hasil diatas, dengan penggunaan model Discovery Learning pada muatan IPA kelas V Semester II di SDN Jogoyitnan Wonosobo sejalan dengan pemerolehan hasil tindakan penelitian yang dilaksanakan oleh (Ana, 2019) dengan memakai model Discovery Learning bisa membantu pengajar menaikan output belajar siswa dibuktikan dengan rerata hasil belajar siswa yaitu 87,5 daya serap87,5 dan ketuntasan hasil belajar siswa telah mencapai $100 \%$ menunjukkan penelitian dinyatakan berhasil. Berikutnya penelitian yang mendukung dilakukan oleh (Panjaitan et al., 2020) bahwa penerapan Discovery Learning bisa mmeningkatkan keterampilan guru dan hasil belajar siswa terbukti melalui peningkatan presentase ketuntasan klasikal hasil belajar siswa dan rerata hasil belajar siswa yang diperoleh tiapsiklus.

\section{KESIMPULAN}

Berdasar hasil dan pembahasan penelitian tindakan kelas tentang peningkatan hasil belajar IPA dengan Discovery Learning berbantu media audio visual di kelas V SDN Jogoyitnan Wonosobo, disimpulkan beberapa hal berikut : (1) Aktivitas siswa kelas V SDN Jogoyitnan Wonosobo pada pembelajaran IPA melalui model Discovery Learning berbantu media audio visual mengalami kenaikan tiap siklusnya. Aktivitas siswa di siklus I mendapatkan rerata skor 14,15 dengan kriteria cukup, di siklus II mendapatkan rerata skor 17,52 kriteria baik. (2) Hasil belajarsiswa kelas V SDN Jogoyitnan Wonosobo pada pembelajaran IPA melalui model Discovery Learning berbantuan media audio visual mengalami peningkatan pada setiap siklus. Ketuntasan belajar pada prasiklus adalah $42 \%$ dengan kriteria sangat rendah. Pada siklus I mencapai $53 \%$ kriteria sedang. Pada siklus II capai $76 \%$ kriteria tinggi. Hasil belajar meliputi hasil belajar ranah pengetahuan. (3) Berdasar hasil wawancara tak terstruktur kepada peserta didik, bahwa peserta didik lebih menyukai pembelajaran dengan model Discovery Learning dikarenakan belajar dengan melakukan percobaan untuk membuktikan pengaruh kalor terhadap suhu dan wujud benda sehingga pengetahuan yang didapat akan lebih utuh dan bermakna dalam kehidupan sehari-hari.

\section{DAFTAR PUSTAKA}

Ana, N. Y. (2019). PENGGUNAAN MODEL PEMBELAJARAN DISCOVERY LEARNING DALAM PENINGKATAN HASIL BELAJARAN SISWA DI SEKOLAH DASAR. Pedagogi: Jurnal Ilmu Pendidikan, 18(2). https://doi.org/10.24036/fip.100.v18i2.318.000-000

Aqib, Z., \& Amrullah, A. (2018). ptk penelitian tindakan kelas teori dan aplikasinya. Ptk Penelitian Tindakan Kelas Teori Dan Aplikasinya.

Depdiknas. (2003). Undang-Undang Nomor 20 Tahun 2003 Tentang Sistem Pendidikan Nasional. In Jakarta: Depdiknas (Vol. 33).

Mahartati, I. G. (2017). Meningkatkan Motivasi dan Hasil Belajar Tematik Peserta Didik dengan Mengoptimalkan Penerapan Model Discovery Learning di SD Negeri 3 Cakranegara I. Jurnal Kependidikan, LPPM IKIP Mataram, 16(3).

Panjaitan, W. A., Simarmata, E. J., Sipayung, R., \& Silaban, P. J. (2020). Upaya Meningkatkan Hasil Belajar Siswa Menggunakan Model Pembelajaran Discovery Learning di Sekolah Dasar. Jurnal Basicedu, 4(4). https://doi.org/10.31004/basicedu.v4i4.549

PENDEKATAN REALISTIK DALAM PEMBELAJARAN MATEMATIKA. (2012). Jurnal Peluang, 1(1).

Purwanto, Y., \& Riadi, I. (2013). Implementasi Multimedia Sebagai Media Pembelajaran. Jurnal Sarjana Teknik Informatika, 1(1).

Sugiyono, D. (2018). Metode penelitian kuatintatif, kualitatif dan R \& D / Sugiyono. In Bandung: Alfabeta. 
704 Peningkatan Hasil Belajar IPA dengan Discovery Learning Berbantuan Media Audio Visual di Sekolah Dasar - Hendika Whesli , Agustina Tyas Asri Hardini DOI: https://doi.org/10.31004/edukatif.v3i3.345

Suharsimi, A. (2007). Penelitian Tindak Kelas (PTK). In LPMP Yogyakarta.

Susanto, A. (2013). Teori Belajar dan Pembelajaran di SD. In Biomass Chem Eng (Vol. 49, Issues 23-6).

Susmiati, E. (2020). Meningkatkan Motivasi Belajar Bahasa Indonesia Melalui Penerapan Model Discovery Learning dan Media Video Dalam Kondisi Pandemi Covid-19 bagi Siswa SMPN 2 Gangga. Jurnal Paedagogy, 7(3). https://doi.org/10.33394/jp.v7i3.2732

Syah, M. (2010). Psikologi Pendidikan dengan pendekatan Baru. In Psikologi Pendidikan dengan pendekatan Baru. 